\title{
Revision of the genus Attemsostreptus Verhoeff, 1941 with description of a new species from Tanzania and notes on the tribe Trachystreptini Cook, 1896 (Spirostreptida, Diplopoda)
}

\author{
Nesrine AKKARI ${ }^{1, *}$ \& Henrik ENGHOFF ${ }^{2}$ \\ ${ }^{1}$ Naturhistorisches Museum Wien, Burgring 7, A-1010 Vienna, Austria. \\ ${ }^{2}$ Natural History Museum of Denmark, University of Copenhagen, Universitetsparken 15, \\ DK-2100 Copenhagen Ø, Denmark. \\ ${ }^{*}$ Corresponding author: nesrine.akkari@nhm-wien.ac.at \\ ${ }^{2}$ Email: henghoff@snm.ku.dk \\ ${ }^{1}$ urn:1sid:zoobank.org:author:DC6FB247-5F4F-4700-9DB6-6588A99370A0 \\ ${ }^{2}$ urn:lsid:zoobank.org:author:FB09A817-000D-43C3-BCC4-2BC1E5373635
}

\begin{abstract}
We revise the genus Attemsostreptus Verhoeff, 1941 based on type material of the type species, A. costatus Verhoeff, 1941, synonymise A. orobius (Kraus 1958) with A. costatus and describe a second species of the genus, $A$. reflexus sp. nov., collected from Kimboza Forest Reserve in Tanzania, and discuss the dubious tribe Trachystreptini.
\end{abstract}

Keywords. Millipedes, new species, synonymy, Tanzania, Trachystreptini.

Akkari N. \& Enghoff H. 2019. Revision of the genus Attemsostreptus Verhoeff, 1941 with description of a new species from Tanzania and notes on the tribe Trachystreptini Cook, 1896 (Spirostreptida, Diplopoda). European Journal of Taxonomy 575: 1-12. https://doi.org/10.5852/ejt.2019.575

\section{Introduction}

The genus Attemsostreptus was first erected by Veroheff in 1941 to accomodate the species he then described from the mountains in Tanzania's Morogoro Region, Attemsostreptus costatus Verhoeff, 1941. The genus remained monotypic for over forty years until Krabbe (1982) assigned to it a second species Attemsostreptus orobius (Kraus, 1958) described in the genus Lophostreptus (Kraus 1958). In her work on the systematics of Spirostreptida, Krabbe (1982) provided a diagnosis for the genus based on the gonopod structures and speculated that $A$. orobius might be a junior synomym to A. costatus, which would bring the genus back to the monotypic status.

A few spirostreptids collected during the 1990s by the NGO 'Frontier Tanzania' and kept in the Natural History Museum of Denmark were recently studied and turned out to represent a new species that we describe here and assign to Attemsostreptus. We formally synonymise A.orobius (Kraus, 1958) with A. costatus Verhoeff, 1941, based on Krabbe (1982) and on the study of type material of A. costatus kept in the Zoologische Staatssammlung München in Germany. 


\section{Material and methods}

All studied specimens are preserved in 75\% ethanol. Measurements and photographs were obtained with a Nikon DS-F2.5 camera mounted on a Nikon SMZ25 stereo microscope, using NIS-Elements Microscope Imaging Software with an Extended Depth of Focus (EDF) patch. Images were processed with Adobe Photoshop CS6 and assembled in Adobe InDesign CS6.

Terminology follows Hoffman (2008) and Enghoff (2017).

\section{Institutional abbreviations}

HNHM = Hungarian Natural History Museum

NHMW $=$ Naturhistorisches Museum Wien

NHMD = Natural History Museum of Denmark (Zoological Museum), University of Copenhagen

$\mathrm{ZSM}=$ Zoologische Staatssammlung München

\section{Morphological abbreviations}

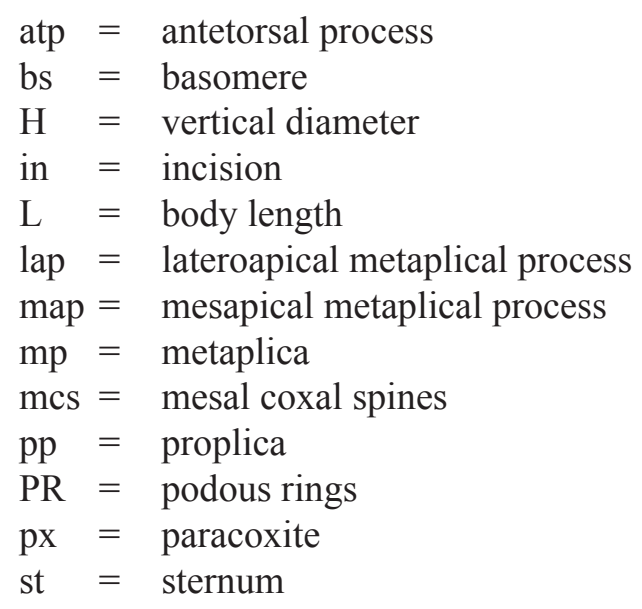

\section{Results}

Order Spirostreptida Brandt, 1833

Family Spirostreptidae Pocock, 1894

Tribe Trachystreptini Cook, 1896

Genus Attemsostreptus Verhoeff, 1941

\section{Diagnosis}

Readily distinguishable from other genera of Spirostreptidae by the extremely long, slender lateral metaplical processes, in combination with the 'trachystreptinine' habitus, i.e., with marked longitudinal striae/keels over the entire body ring circumference. Krabbe (1982) presented a more detailed diagnosis, based mainly on male secondary sexual characters, as follows (translated from German and slightly modified): collum without longitudinal keels. First pair of legs with strong 'shoulders'; the outer margin of the coxosternum smooth with 4 lateral small setae; prefemoral processes divergent, short, triangular with gently rounded margins, prefemora and prefemoral processes with pores. Gonopod sternum low and small; coxae slender, proplica (pp) simple, straight, bearing a few setae distally; metaplicae (mp) apically round to angular with extremely elongated lateral processes (lap) tapering into a claw-like apex, distally round to subrectangular; telopodite slender with a long, thin antetorsal process (atp), distal 
to (atp) becoming even slenderer, apex bifurcate with a thin serrated lamella and an acuminate apical process.

\section{Included species}

Attemsostreptus costatus Verhoeff, 1941, Attemsostreptus reflexus sp. nov.

Attemsostreptus costatus Verhoeff, 1941

Fig. 1

Attemsostreptus costatus Verhoeff, 1941: 262-263, plate 12, figs 35-36.

Lophostreptus orobius Kraus, 1958: 11-12, plate 3, figs 30-34. syn. nov.

Attemsotreptus orobius Krabbe 1982: 252-253, fig. 185.

\section{Material examined}

Attemsostreptus costatus Verhoeff, 1941 types (ZSM), 4 micro-preparations of $2 \hat{\jmath} \widehat{\partial}$ and 1 juvenile $\widehat{\partial}$.

TANZANIA 1 1 , juvenile, gonopods, 3 sections of a tergite; ZSM A20042783 - $\hat{\sigma}$ legs 1-7, gnathochilarium, labrum; ZSM A20042784 - $\sigma^{\lambda}$, gonopod in one block; ZSM A200427814 • 1 , gonopods separated in left and right, left and right telopodites, two leg-pairs attached to a portion of sternite; ZSM A20042785.

\section{Descriptive notes on gonopods}

SteRnum (st). Small and simple, lower than paracoxite (px).

Coxa. Proplica (pp) simple, straight and broad, distally with scattered bristles. Metaplica (mp) with a deep mesoapical incision, a rounded mesoapical metaplical process (map) and a long twisted and downturned lateroapical metaplical process (lap). The latter (lap) pointing proximolaterad and ending in claw-like pointed apex.

TELopodite. With a thin and curved antetorsal process (atp) ending in a pointed apex, post-torsal part forming a loop at mid-length, narrowing towards apex, apex bifurcate with a thin serrated lamella (sl) and an acuminate apical process.

\section{Comments}

Verhoeff (141: 263, pl. 12, fig. 36) described serrations on the margins of the 'solenomere' and three projections at the apex of the 'telomere'. The descriptions and drawings of Krabbe (1982: 252 fig. 185) and Kraus (1985: 1-12, figs 30-34) match our observations.

Attemsostreptus reflexus sp. nov. urn:lsid:zoobank.org:act:ACE58179-F898-43CD-A9CC-BE4121D77A8C

Figs $2-5$

\section{Diagnosis}

A species of genus Attemsostreptus that differs from A. costatus in the shape of the coxal apical and lateral processes, and in the presence of coxal distomesal spines. 


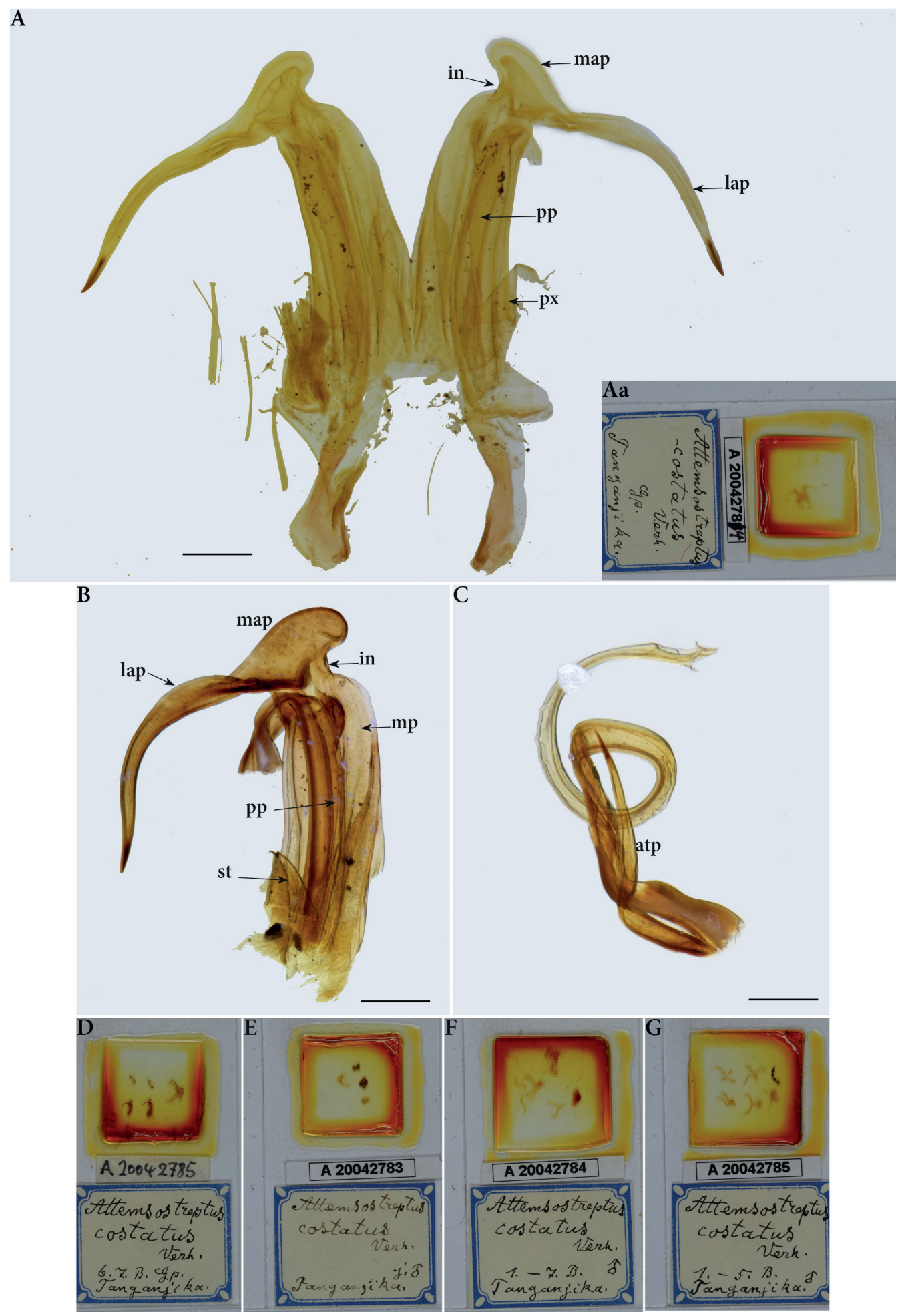

Fig. 1. Attemsostreptus costatus Verhoeff, 1941, type material ZSM. A. Gonopods, anterior view. Aa. Overview of slide A 200427814, containing the gonopods. B. Slide A20042785, left gonopod, anterior view. C. Telopodite. D-G. Overview of Verhoeff's slides (ZSM) A20042785, A20042783, A20042784, A20042785. For abbreviations, see Material and methods. Aa, D-G photo credit J. Spelda. Scale bars: A-C $=0.5 \mathrm{~mm}$; Aa, D-G: images not to scale. 


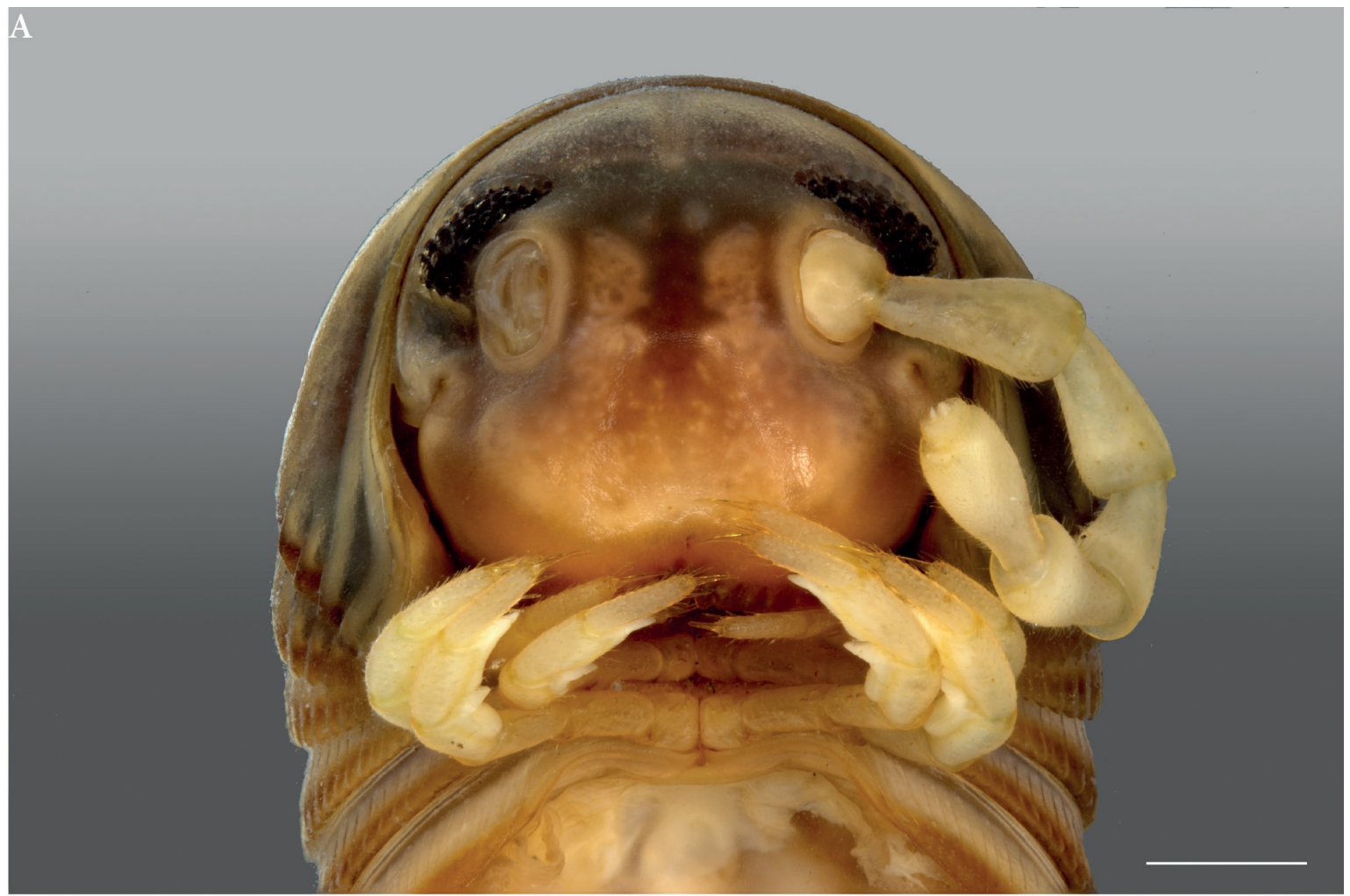

$\bar{B}$

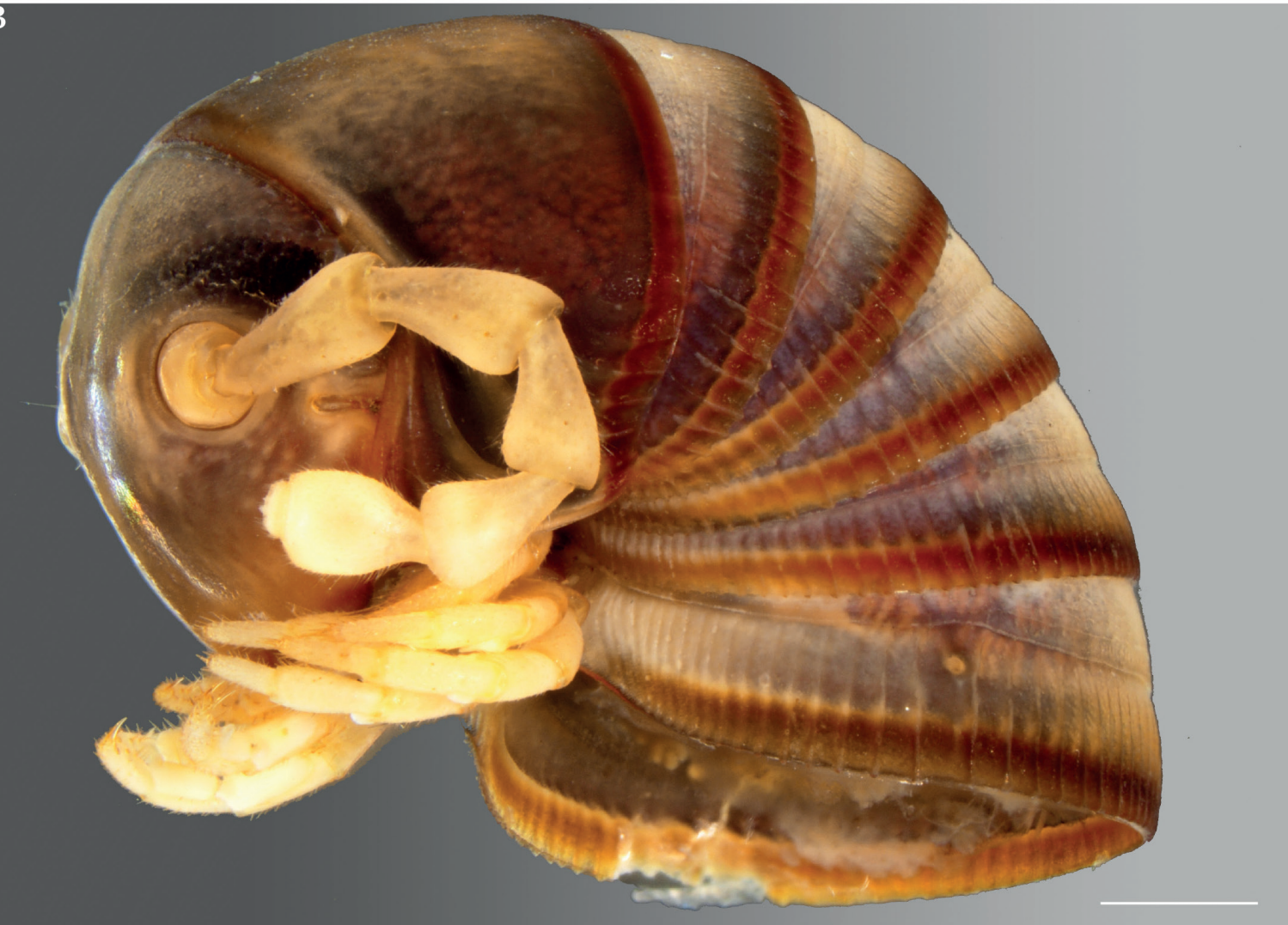

Fig. 2. Attemsostreptus reflexus sp. nov., male holotype (NHMD607065), head and anteriormost body rings. A. Ventral view. B. Lateral view. Scale bar: $1 \mathrm{~mm}$. 


\section{Etymology}

The species epithet is a Latin adjective meaning 'turned back' and referring to the shape of the lateroapical metaplical process of the gonopod.

\section{Material examined}

\section{Holotype}

TANZANIA 1 $1 \widehat{\jmath}$, missing posterior part, dissected; Morogoro Reg., Morogoro Distr., Kimboza Forest Reserve; 3748' E, 0701' S; Jan.-Mar. 1994; Frontier Tanzania leg.; NHMD607065.

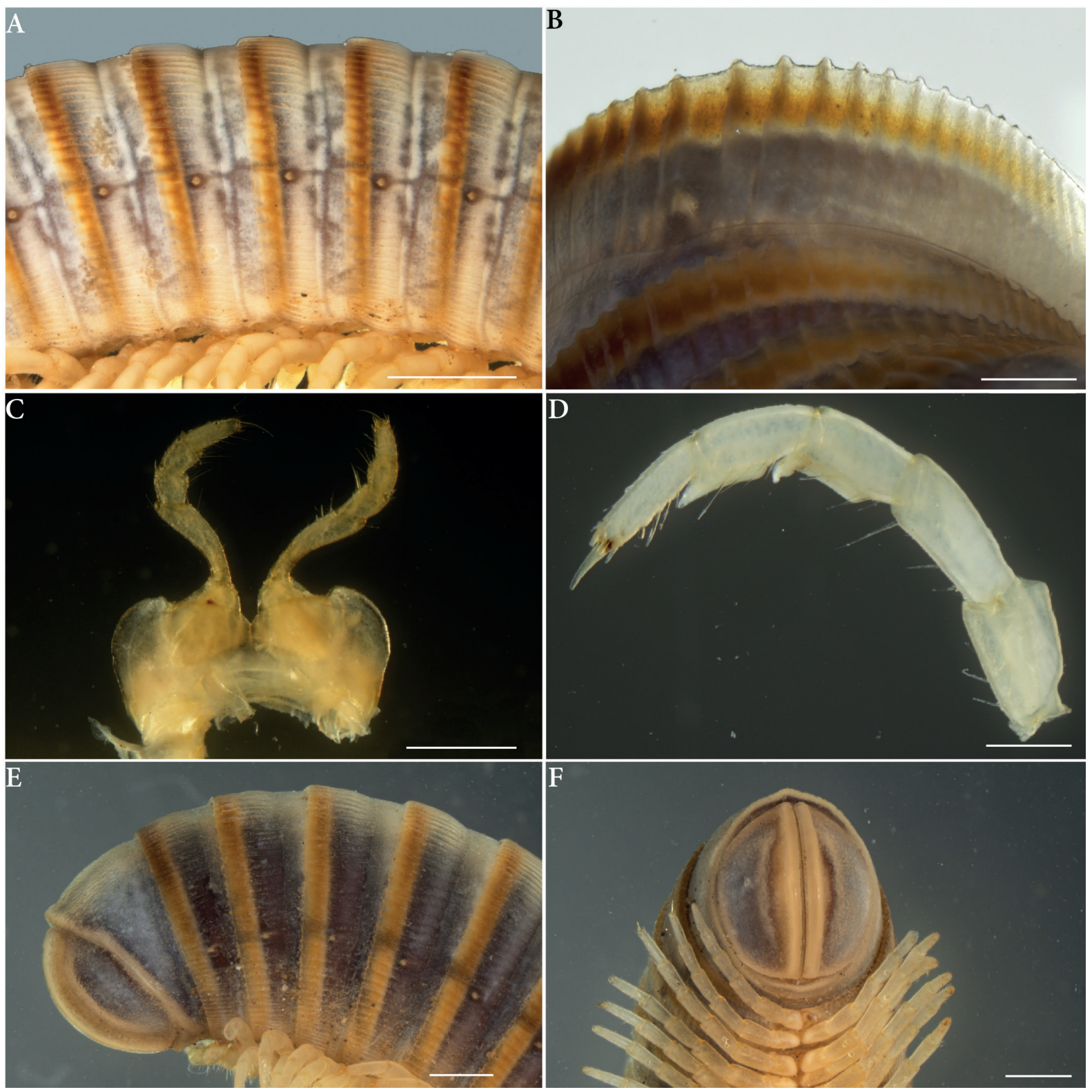

Fig. 3. Attemsostreptus reflexus sp. nov., external structures. A. Midbody rings in lateral view, telson towards the left, female paratype. B. Limbus, male holotype (NHMD607065). C. First pair of legs, male holotype (NHMD607065). D. Midbody leg with soft pads, male holotype (NHMD607065). E. Posteriormost body rings and telson in lateral view, female paratype. F. Posteriormost body rings and telson in ventral view, female paratype. Scale bar: $1 \mathrm{~mm}$. 


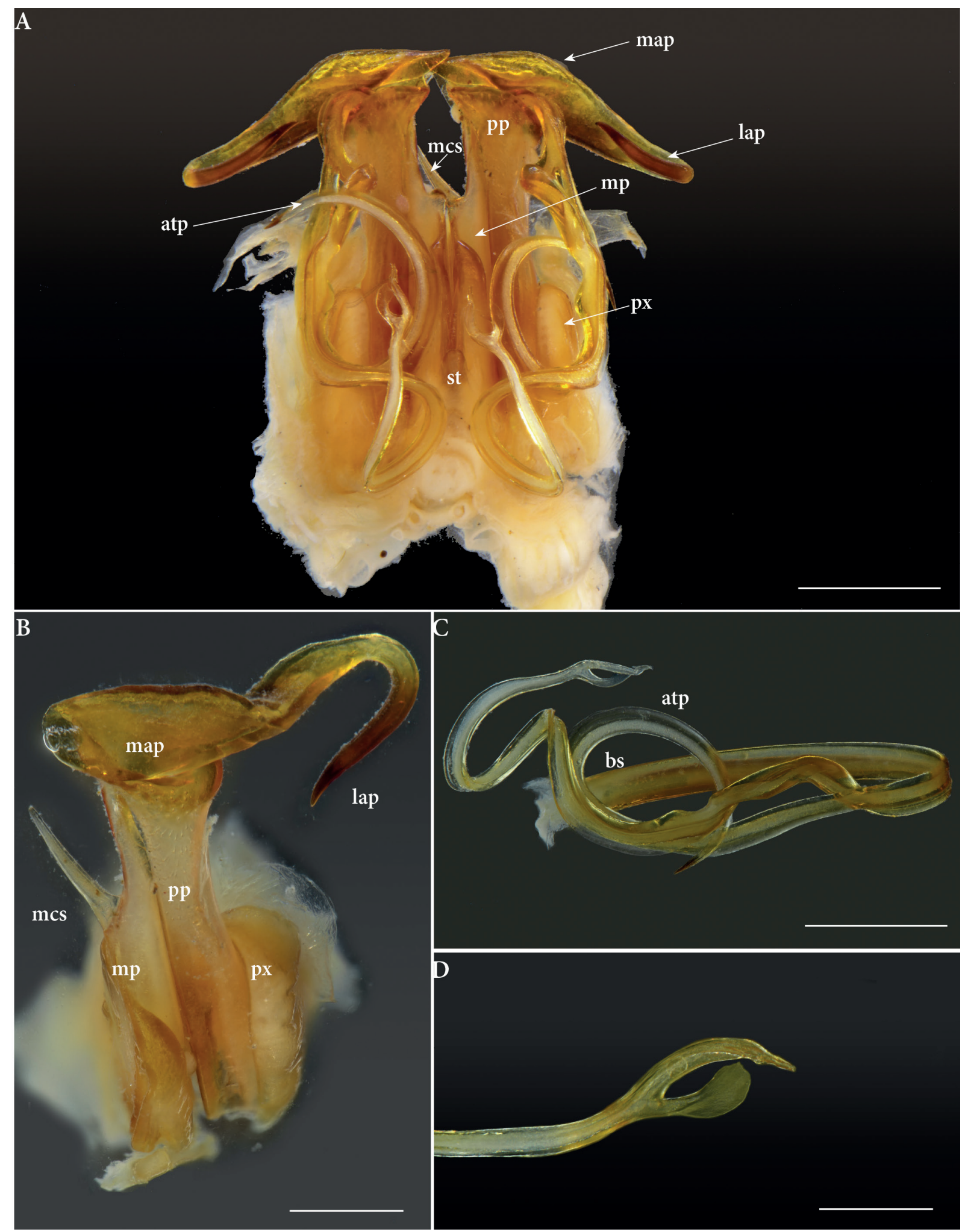

Fig. 4. Attemsostreptus reflexus sp. nov., male holotype (NHMD607065), gonopods. A. Gonopods, anterior view. B. Right gonopod, antero-apical view. C. Telopodite. D. Tip of telopodite. For abbreviations, see Material and methods. Scale bars: $A=1 \mathrm{~mm}$; $-\mathrm{D}=0.5 \mathrm{~mm}$. 


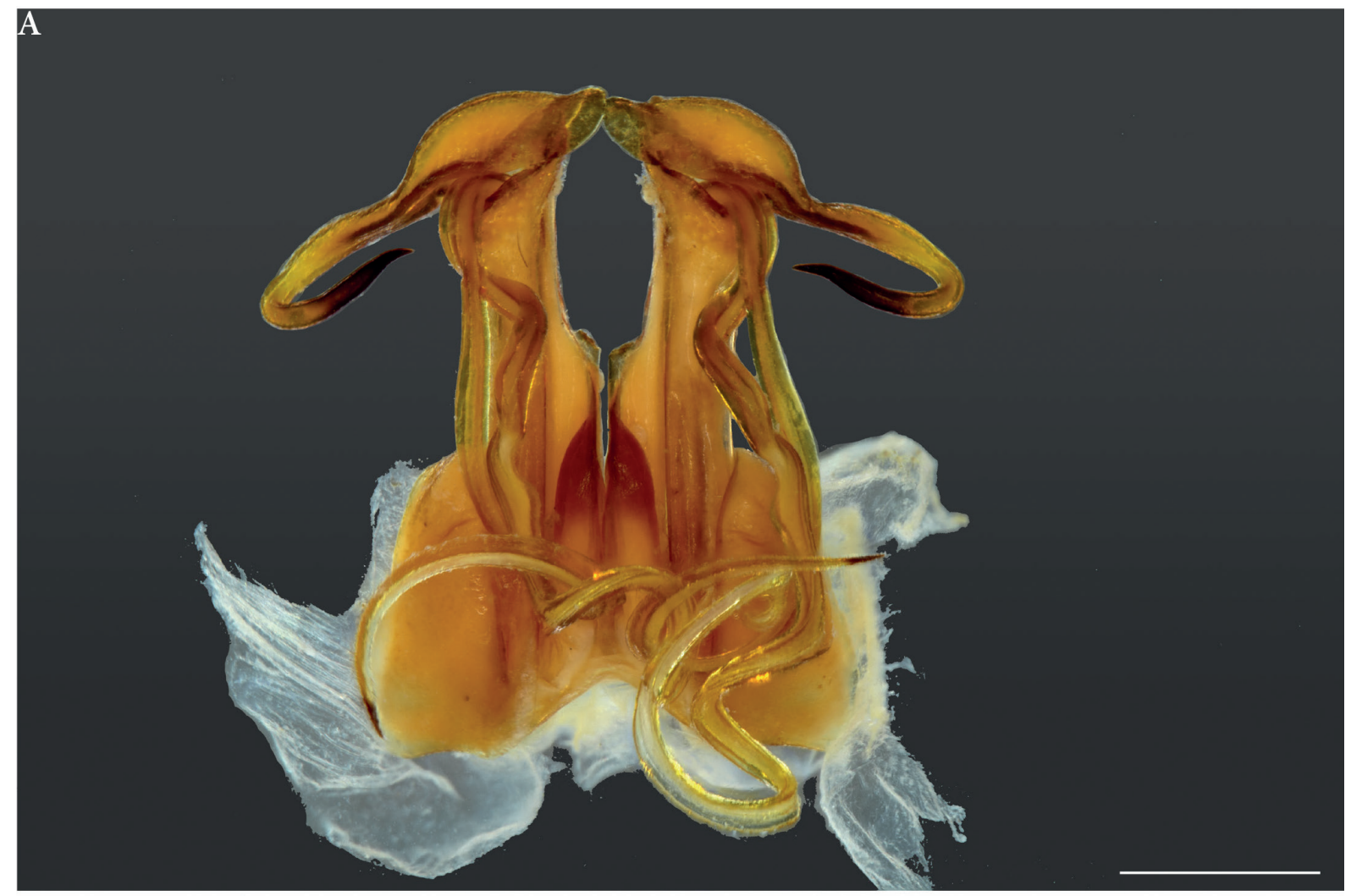

B

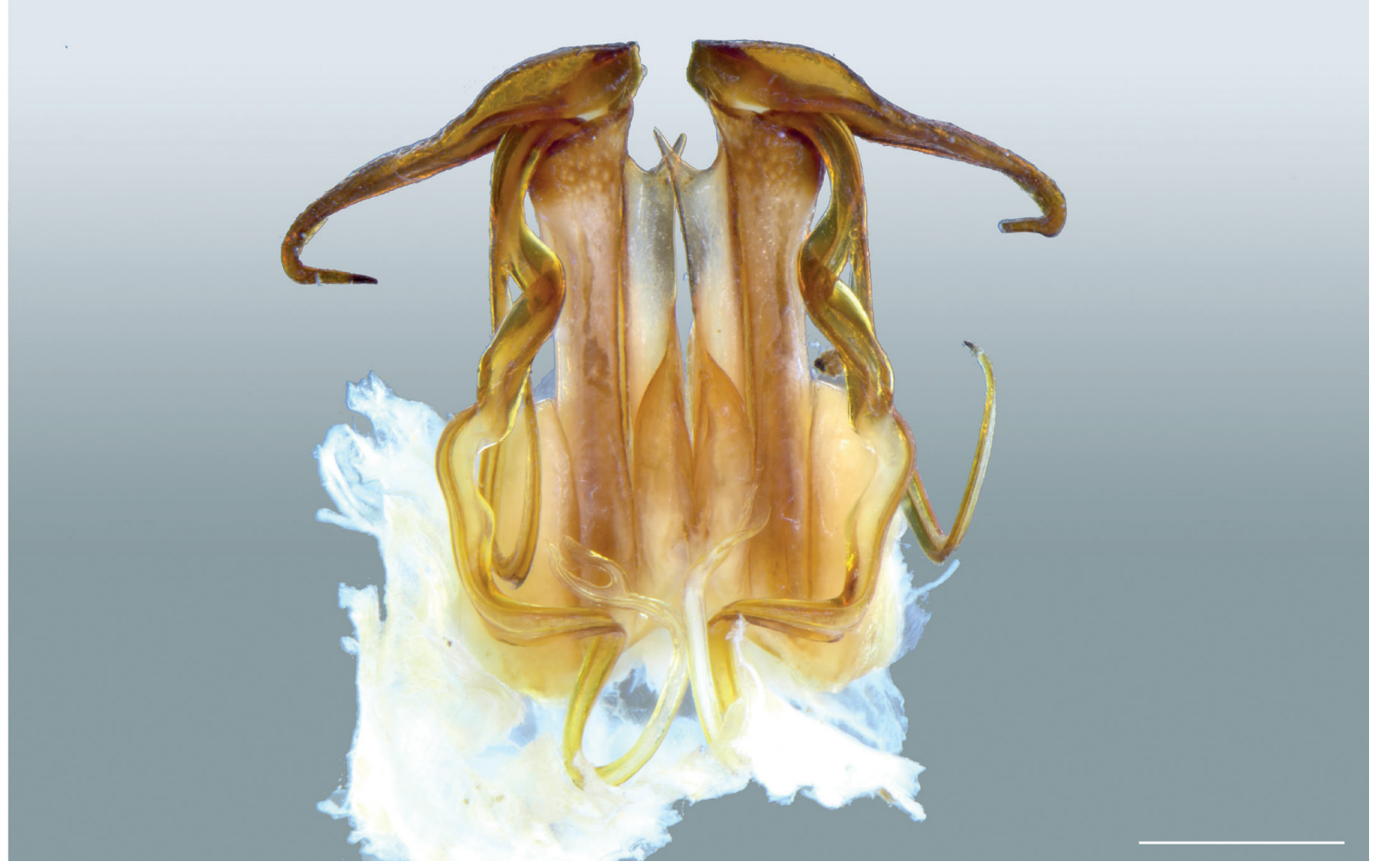

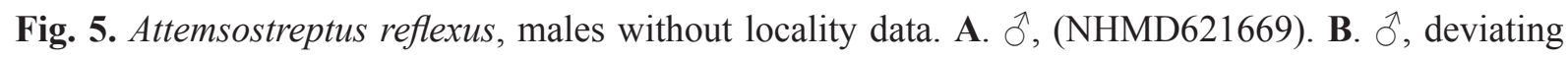
gonopods (HNHM diplo-1697). Scale bar: $1 \mathrm{~mm}$. 


\section{Paratypes}

TANZANIA $-1 \hat{0}$, missing posterior part; same collection data and repository as for the holotype; NHMD607073 4 4 우, three of which broken in half and one missing posterior part; same collection data and repository as for the holotype; NHMD607073.

\section{Other material examined}

TANZANIA $\cdot 1 \hat{\delta}$, without data, mesal coxal spines (mcs) short, originating more distally than in the type specimens, mesoapical metaplical process (map) more truncate than round, distolateral spine maybe not quite so extraordinarily long, only $51 \mathrm{PR}$ vs $56 \mathrm{PR}$ in females from type series, body length (L) $65 \mathrm{~mm}$, vertical diameter (H) $4.0 \mathrm{~mm}$; NHMD621669 • 1 त, HNHM diplo-1697, without data, exactly like type specimens except that (mcs) are broken, 53 PR, L $70 \mathrm{~mm}, \mathrm{H} 4.3 \mathrm{~mm}$.

\section{Description}

MEASUREMENTS. Holotype $\widehat{\delta}: \mathrm{H}=4.3 \mathrm{~mm}$, broken in three parts, missing posterior end. Paratypes $\widehat{\delta}: \mathrm{H}=$ $4 \mathrm{~mm}$; broken, missing posterior end. Females: $\mathrm{L}=78.5-81.2 \mathrm{~mm} ; \mathrm{H}=4.8-5.2 \mathrm{~mm} ; 56 \mathrm{PR}$.

Colour (Figs 2-3). After several years in ethanol, orange-reddish-brown, colour more intense at margin of the posterior half of metazonites, prozonites lighter with a hint of chestnut at the lateral margins. Head dark brown in occipital area, sputtered with yellowish on frons and reddish to yellowish brown on labrum and gnathochilarium. Antenna and legs yellowish.

HeAD (Fig. 2). Four supralabral setae. Antennae reaching back to body ring 6. Eyes reaching slightly beyond mesal margin of antennal socket, each with ca 10 vertical rows of ommatidia, ca 5 horizontal rows, ca 35 ommatidia. Mandible as in Tropostreptus (Enghoff 2017): stipes in males with a small apicoventral lobe; odontomere long, moveable; sectile edge of psectromere with ca 5 lobes; ca 12 pectinate lamellae; one wide molar furrow. Gnathochilarium: prementum simple, not depressed; mentum with deep depression basally delimited by sharp ridge, as in Pseudotibiozus (Enghoff \& Larsson 2018: fig. 3); stipites with basal row of setae adjacent to mentum, apicolaterally with field of many setae, distally with swelling harbouring one modified seta, as in Pseudotibiozus (Enghoff \& Larsson 2018: fig. 3).

Collum (Fig. 2). With protruding antero-ventral lobes in males. Three or four lateral furrows. No antennal groove.

Body Rings (Figs 2B, 3A, E). Prozonae with non-consipicuous furrows. Metazonae with regular longitudinal striae on entire body ring circumference, areas between striae elevated as ridges, ridges projecting beyond posterior margin of ring (Fig. 3B). Ozopore round, visible as bright spot rimmed with grey at the middle of metazona, behind suture (Fig. 3A), latter thin and sometimes curving at level of ozopore. Pleurotergal lobes meeting behind posterior pair of legs on each body ring.

Legs (Figs 2-3C-D). Length ca $4 \mathrm{~mm}$, slightly shorter in females. Males with postfemoral and tibial pads from third pair until beyond midbody (Fig. 2A), pads decreasing in size posteriorly, absent from posteriormost legs. First pair of legs in male (Fig. 3D) similar to those of A. costatus as described by Krabbe (1982).

Telson (Fig. 3E-F). Preanal ring with straight dorsal margin. Anal valves with raised median margins forming blunt lips, flanked by distinct grooves, i.e., of the "fossate" type sensu Hoffman (2011).

Gonopods. (Figs 4-5). Sternum (st) small and simple, lower than paracoxite (px).

Coxa. Proplica (pp) simple, straight and broad, distomesal corner sharp, distal margin almost straight, oblique, surface in distal part with scattered bristles. Metaplica (mp) broad and stout; mesal margin 
straight, in basal part folded laterad as broad duplicature, subapically with large distad spine (mcs); in some specimens, (mcs) smaller and inserted more distally than in the holotype; metaplica apically gently rounded, mesoapical metaplical process (map) protruding as narrow ovoid mesal lobe, truncate in a few specimens (Fig 5B), meeting medially and totally lacking the meso-apical incision observed in $A$. costatus, laterally showing a strong constriction and protruding as lateroapical metaplical process (lap). This process (lap) very long, and strongly curved, first directed laterad, then making a U-turn and pointing distomesad to mesad in most specimens, ending in claw-like pointed apex.

Telopodite. With a thin and curved antetorsal process (atp) ending in a pointed apex, post-torsal part long, with several torsions and an incomplete loop, thereafter narrowing towards apex and bifurcating into a thin serrated lamella (sl) and an acuminate apical process.

\section{Distribution}

Kimboza Forest Reserve, Morogoro.

\section{Discussion}

Attemsostreptus was placed in "Trachystreptini" by Verhoeff (1941) who, however, questioned this assignment because although the body ring sculpture of Attemsostreptus suggested Trachystreptini, the gonopods of A. costatus in Verhoeff's view are more similar to those of Spirostreptus (in the then prevalent sense, cf. Hoffman et al. 2001) than to those of the then best known trachystreptinine genus, Lophostreptus Cook, 1895. Demange \& Mauriès (1975) analysed the trachystreptinine spirostreptids in great detail and provided a revised classification. They discussed the problems with delimiting Trachystreptini because the 'diagnostic' metazonital keels are developed to very different degrees. Demange \& Mauriès (1975) mentioned another character which they regarded as a valid character for Trachystreptini, viz the shape of the lateral lobes of the collum. According to these authors, a part of the anterior surface of the collar lobes is flexed towards the head capsule, thereby forming a cavity for accommodating the antennae. Hoffman (1980: 85) expressed general skepticism towards the internal divison of Spirostreptidae into subfamilies/tribes, and Krabbe (1982) like Verhoeff (1941) placed the name Trachystreptini in quotes, referred to it is a "Formengruppe" (morpho-group) and implicitly argued against its monophyly. Based on personal scrutiny of original literature as well as specimens from NHMW and NHMD, we can confirm that the collum character emphasized by Demange \& Mauriès (1975) is not present in all "trachystreptinine" genera. Whereas in some species, e.g., Furcillogonus frigidus Demange \& Mauriès, 1975, and Calostreptus chelys Cook, 1895, the antennal grooves are very prominent, grooves are completely absent in the genus Attemsotreptus, as they are in Lophostreptus ptilostreptoides Carl, 1909, L. armatus Pocock, 1896, Anastreptus scalatus (Karsch, 1881) and Bucinogonus kandti (Carl, 1909). An antennal groove is present in Humilistreptus Demange, 1958 (= Guviogonus Demange \& Mauriès, 1975), a genus which includes a species with a "trachystreptinine" habitus as well as some without (Krabbe 1982).

If the relationships of Attemsostreptus to other spirostreptids thus remain unclear, the genus as such is well characterised and may be regarded as monophyletic based on the remarkable, very long and clearly apomorphic lateroapical metaplical processes.

The type locality of Attemsostreptus reflexus sp. nov., Kimboza Forest Reserve, is situated in the foothills of the Uluguru Mts, see Doggart et al. (2004) for further information. Several millipede species have previously been recorded from Kimboza F.R., viz Hyperbolus morogoroensis (Kraus, 1958) (Pachybolidae), Xystopyge proplicatus Frederiksen \& Enghoff, 2012 (Odontopygidae), Lophostreptus ptilostreptoides Carl, 1909, Obelostreptus proximospinosus Krabbe, 1982, and Tropostreptus sigmatospinus Enghoff, 2017 (Spirostreptidae), Lyodesmus kimboza Hoffman, 1990, 
L. rubidopsis (Kraus, 1958), and Rhododesmus planus (Kraus, 1958) (Oxydesmidae) (Enghoff et al. 2016; Enghoff 2017).

The only known congener of $A$. reflexus, viz A. costatus, is also known only from the Uluguru Mts, suggesting a very restricted distribution area of the genus Attemsostreptus.

\section{Acknowledgements}

We are grateful to Frontier Tanzania for collecting the material of the new species described here, to Stefan Friedrich and Jörg Spelda (ZSM) for making the type material of K.W. Verhoeff available to us for study and for the overview photos of the slides, and to Eszter Lazányi, László Dányi and Dorottya Angyal for arranging a loan of material from HNHM. Sergei Golovatch and an anonymous reviewer provided useful comments on a previous version of the manuscript.

\section{References}

Demange J.M. 1958. Un nouveau genre et une nouvelle espèce de Myriapodes du Mont Nimba (Guinée). (Diplopodes Spirostreptidae). Bulletin du Muséum national d'histoire naturelle 2 (30): 271-275.

Demange J.M. \& Mauriès J.-P. 1975. Myriapodes - Diplopodes des Monts Nimba et Tonkoui (Côte d'Ivoire, Guinée) récoltés par M. Lamotte et ses collaborateurs de 1942 à 1961 . Annalen van het Koninklijk Museum voor Midden-Afrika - Zoologische wetenschappen 212: 1-192.

Doggart N., Lovett J., Mhoro B., Kiure J. \& Burgess N. 2004. Biodiversity surveys in the forest reserves of the Uluguru Mountains. Part I: An overview of the biodiversity of the Uluguru Mountains. The Wildlife Conservation Society of Tanzania. Available from http://www.easternarc.or.tz/groups/webcontent/documents/pdf/Ulugurus $\% 20 \mathrm{draft} \% 20 \mathrm{Part} \% 201 \% 20$ v.5.pdf [accessed 22 Oct. 2019].

Enghoff H. 2017. A new East African genus of spirostreptid millipedes (Diplopoda, Spirostreptida, Spirostreptidae), with notes on their fungal ectoparasite Rickia gigas. Zootaxa 4273 (4): 501-530.

https://doi.org/10.11646/zootaxa.4273.4.3

Enghoff H. \& Larsson T.B. 2018. Pseudotibiozus Demange, 1970 - millipedes of the Eastern Arc mountains, Tanzania (Diplopoda, Spirostreptida, Spirostreptidae). Zootaxa 4425 (3): 541-554.

https://doi.org/10.11646/zootaxa.4425.3.7

Hoffman R.L. 2008. Two new genera of spirostreptid millipeds from central Africa, with a new terminology for male genitalia in the family Spirostreptidae (Diplopoda Spirostreptida). Tropical Zoology 21: 167-186. Available from http://www.fupress.net/index.php/tropicalzoology/article/viewFile/2762/2480 [accessed 22 Oct. 2019].

Hoffman R.L. 2011. A review of the milliped genus Haplogonopus with commentary on the so-called "Charactopygus-Bildung" modification of spirostreptid paraprocts (Diplopoda: Spirostreptidae). Zootaxa 2734: 53-62. https://doi.org/10.11646/zootaxa.2734.1.4

Hoffman R.L., Golovatch S.I. \& Hamer M. 2001. Identities of the milliped genera Spirostreptus Brandt, 1833 and Spiropoeus Brandt, 1833 (Diplopoda, Spirostreptida, Spirostreptidae). Myriapodologica 7 (5): 35-56. https://doi.org/10.11646/zootaxa.4247.3.8

Krabbe E. 1982. Systematik der Spirostreptidae (Diplopoda, Spirostreptomorpha). Abhandlungen des naturwissenschaftlichen Vereins in Hamburg, N.F., 24: 1-476.

Kraus O. 1958. Myriapoden aus Ostafrika (Tanganyika Territory). Veröffentlichungen aus dem ÜberseeMuseum Bremen Reihe A (3): 1-16. 
Verhoeff K.H.1941. Studien an äthiopischen Diplopoden. Jenaische Zeitschrift für Naturwissenschaft 73: 231-274.

Manuscript received: 31 May 2019

Manuscript accepted: 15 July 2019

Published on: 7 November 2019

Topic editor: Rudy Jocqué

Desk editor: Eva-Maria Levermann

Printed versions of all papers are also deposited in the libraries of the institutes that are members of the EJT consortium: Muséum national d'histoire naturelle, Paris, France; Meise Botanic Garden, Belgium; Royal Museum for Central Africa, Tervuren, Belgium; Royal Belgian Institute of Natural Sciences, Brussels, Belgium; Natural History Museum of Denmark, Copenhagen, Denmark; Naturalis Biodiversity Center, Leiden, the Netherlands; Museo Nacional de Ciencias Naturales-CSIC, Madrid, Spain; Real Jardín Botánico de Madrid CSIC, Spain; Zoological Research Museum Alexander Koenig, Bonn, Germany; National Museum, Prague, Czech Republic. 